\title{
Biochemical, Clinical and Prevalence Characteristics of Chronic Kidney Disease Secondary to Arterial Hypertension
}

\author{
TEIM BAAJ ${ }^{1}$, MIRCEA BOTOCA ${ }^{\mathbf{1}}$, OCTAVIAN MARIUS CRETU ${ }^{1}$, \\ AHMED ABU-AWWAD ${ }^{1 *}$, ELENA ARDELEANU ${ }^{1}$, IOAN MUSTA ${ }^{1}$, IOAN TILEA ${ }^{2}$, \\ SHAMSA BAAJ ${ }^{3}$, LAURENTIU SIMA ${ }^{1}$, ANDREI PAUNESCU ${ }^{1}$, ANDREI RUSMIR ${ }^{1}$, \\ SILVIU LATCU ${ }^{1}$, SEBASTIAN PLESA ${ }^{1}$, ADINA ELENA PROTESI ${ }^{1}$, ALIN CUMPANAS ${ }^{1}$ \\ ${ }^{1}$ Victor Babes University of Medicine and Pharmacy, 2 Eftimie Murgu Sq., 300041, Timisoara, Romania \\ ${ }^{2}$ University of Medicine and Pharmacy Tirgu Mures, 38 Gh. Marinescu Str., 540134, Tirgu Mures, Romania \\ ${ }^{3}$ Harvard Medical School, 55 Fruit Street, GRB 444 Boston, MA 02114, SUA
}

\begin{abstract}
Hypertension has been recognized as an important cause of chronic kidney disease (CKD). As the most important part of the hypertensive patients are managed in primary care, implementation of routine early detection of CKD by determination of albuminuria and the estimated glomerular filtration rate (eGFR) at this level is essential for diagnosis and prevention. The present study demonstrated that prevalence of chronic kidney disease in hypertensive patients was 13.32\%, being higher in female than men, with old age and in the presence of diabetes mellitus and associated cardiovascular diseases. The reduction of the eGFR depended significant statistically on age, gender and presence of diabetes mellitus, while albuminuria depended on the presence of diabetes and old age. Early detection of CKD in hypertensive patients permits optimal treatment of cardiovascular risk factors, especially concerning the reduction of high blood pressure, therapy with renin-angiotensin system blockers in order to reduce albuminuria and the progression of eGFR decline and treatment of hyperlipidaemia.
\end{abstract}

Keywords: KDIGO stages; hypertension; prevalence; biochemical characteristics

\section{Introduction}

Chronic kidney disease (CKD) is present in a significant part of the adult hypertensive population of Romania, contributing to a reduced quality of life, high incidence of cardiovascular diseases, end stage chronic kidney disease (ESKD) and to a growing cardiovascular (CV) mortality [1]. The link between hypertension and the kidney is for both entities unfavourable. Hypertension is both a cause and a consequence of CKD, as $80-95 \%$ of patients with CKD associate hypertension. The onset of CKD contribute to the aggravation of hypertension through many mechanisms, especially due to increased systemic vascular resistance and volume overload. Hypertension is the second leading factor, after diabetes, which contributes to the initiation and progression of CKD. The prevalence of CKD has increased in the last decades due to the aging of the population, to the growing prevalence of diabetes, hypertension and obesity [2]. Prevalence of CKD in essential hypertension was reported to be variable, depending on ethnicity, gender, geographical area and associated pathology. In population studies, CKD was present in Japan in about 20\%, in European countries in 10\%-15\% and in Romania in about 6-7\% [3]. In the study of Cepoi [4], made on a large sample of 60.000 adults, the prevalence of CKD in the general population was $7 \%$, being higher in woman than in man and in older population. In other geographic area, as in the United States, it affects $13.1 \%$ of the adult population [5]. The prevalence of CKD in the hypertensive population is even higher, reaching $10-25 \%$. To reduce cardiovascular and renal morbidity and mortality, international guidelines as $2018 \mathrm{ESH} / \mathrm{ESC}$ Guideline for the Management of Hypertension [6] recommend screening for CKD in high risk cardiovascular patients, with the emphasis on hypertension and diabetes mellitus. Prevention actions to stop progression of

*email: ahm.abuawwad@gmail.com 
CKD by strict control of BP values, reduction of albuminuria and correction of cardiovascular risk factors as dyslipidaemia and diabetes are strongly recommended [7]. There are few studies referring to the prevalence, risk factors and characteristics of CKD in Eastern Europe and in Romania. As prevalence of hypertension in Romania has a growing tendency, as demonstrated in the SEPHAR I-III Surveys ( $45 \%$ of the adult population of Romania has hypertension), prevalence of CKD secondary to hypertension also presents a growing trend, which need to be studied [8-10].

The objectives of the present study were: (1) to evaluate the prevalence of CKD secondary to essential hypertension in an adult hypertensive population monitored in Timis County, Romania, (2) to determine the CKD stages of these hypertensive subjects, (3) to study their biochemical and clinical characteristics, and (4) to evaluate the role of associated CV risk factors for CKD development.

\section{Materials and methods}

This is an observational cross-sectional study, effectuated between January 2017 and December 2019 in primary care health centres of Timis Country, Romania. At the study participated 14 general practitioners (GPs), specially trained, from Timiş County offices, cardiologists and internal medicine specialists from Timisoara Medical University "Victor Babes". The study population consisted of hypertensive patients, selected during their visit at the GPs office. Study inclusion criteria were adult patients over 18 years with essential hypertension, old or newly diagnosed. Exclusion criteria were secondary hypertension, febrile illness, mental illness, gestation and acute myocardial infarction. A number of 1214 hypertensive patients were evaluated during this period. A part of the participants did not complete the study, in the final analysis being included 984 subjects (81.06\%), as only they had complete evaluation data. In conformity with the World Medical Association Declaration of Helsinki, at the beginning of the study all participants signed a written informed consent.

The design of the study included 3 visits at the GPs office. The objectives of the first visit were to measure office BP and to obtain demographic, socio-economic and lifestyle data, information about the existing current diseases and family history, by completing study questionnaires. The physical examination included measurements of weight, height and waist. The body mass index (BMI) was expressed as $\mathrm{kg} / 1.73 \mathrm{~m}^{2}$. Blood pressure measurements were done according to the ESC/ESH Hypertension Guidelines [6]: 3 measurements at $2 \mathrm{~min}$ interval, the average of the last two measurements being noticed. All primary care offices used for BP measurement calibrated automated OMRON HEM $7251 \mathrm{G}$ devices. The second visit at the office took place two weeks apart from the first visit. Repeated BP measurements were obtained and urinary albumin to creatinine ratio (ACR) was determined from spot urine with dipsticks by the office nurses. For biochemical analysis $12 \mathrm{~h}$ fasting blood samples and morning spot urine samples were collected. The analyses included total cholesterol (TC), low density lipoprotein cholesterol (LDL-c), high density lipoprotein cholesterol (HDL-c), triglycerides (TG), fasting plasma glucose (FPG), HbA1c, uric acid, creatinine and in selected cases oral glucose tolerance test (OGTT). The laboratory tests were performed in conformity with the standardized procedures by the Synevo Laboratories. Albumin excretion was evaluated calculating the urinary albumin to creatinine ratio (ACR). The presence of microalbuminuria (MAU) was confirmed by the ACR of $30-300 \mathrm{mg} / \mathrm{g}$. ACR $<30 \mathrm{mg} / \mathrm{g}$ defined normalbuminuria and over $300 \mathrm{mg} / \mathrm{g}$ macroalbuminuria (proteinuria). After the second visit, patients diagnosed with CKD were evaluated in cardiology centers for detection of hypertension mediated organ damage. At the third visit, that took place three months after the first visit, final evaluation of biochemical data, diagnosis and treatment efficacy were done.

Based on the classification of the National Kidney Foundation-Kidney Disease Outcomes Quality Initiative (NKF-K/DOQI), CKD was classified into 5 stages. Stage 1 presented signs of kidney damage (albuminuria) with normal glomerular filtration rate $(\mathrm{GFR}) \geq 90 \mathrm{~mL} / \mathrm{min} / \mathrm{m}^{2} ;$ stage 2 presented albuminuria and a mild reduced eGFR of $60-89 \mathrm{~mL} / \mathrm{min} / \mathrm{m}^{2}$; stage 3 was represented by a moderate reduction of eGFR to $30-59 \mathrm{~mL} / \mathrm{min} / \mathrm{m}^{2} \pm$ albuminuria; stage 4 was represented a severe reduction of eGFR to $14-29 \mathrm{~mL} / \mathrm{min} / \mathrm{m}^{2} \pm$ albuminuria; stage 5 presented an eGFR $\leq 15 \mathrm{~mL} / \mathrm{min} / \mathrm{m}^{2}$ or dialysis 
[11]. The GFR was estimated based on the serum creatinine level, using the CKD-EPI equation, corrected for age and gender. Dyslipidaemia diagnosis was based on the following profile, or on treatment: total cholesterol $>200 \mathrm{mg} / \mathrm{dL}$ or LDL-cholesterol $>115 \mathrm{mg} / \mathrm{dL}$ or HDL-cholesterol $<40$ $\mathrm{mg} / \mathrm{dL}$ for men, $<46 \mathrm{mg} / \mathrm{dL}$ for women and triglycerides $>150 \mathrm{mg} / \mathrm{dL}$. The glucose metabolism impairment was evaluated according to the 2012 American Diabetes Association (ADA) Guidelines.

Statistical analysis. The statistical analyses were performed using SPSS version 12.0. Data were presented as frequencies and percentages for qualitative variables and as mean \pm SD for quantitative variables. Differences between groups were assessed with the Pearson $\chi^{2}$ for percentages and the Student $t$ test for mean values. To determine the correlations between hypertension and risk factors, the logistic regression analysis was used. The independent variables with $\mathrm{p}<0.05$ were considered as having statistical significance. Odds ratios with $95 \%$ confidence interval (CI) were calculated for CKD stages. Logistic regression analysis determined the independent predictors of CKD in the study population.

\section{Results and discussions}

The prevalence of chronic kidney disease in the studied hypertensive population, consisting of 984 cases, was $13.32 \%$ (131 cases).

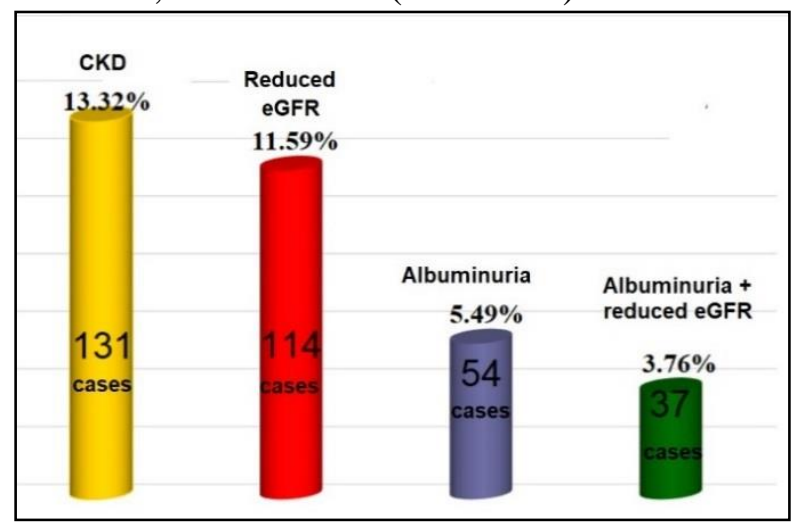

Figure 1. Prevalence of diagnosis criteria for chronic kidney disease in the hypertension with chronic kidney disease group

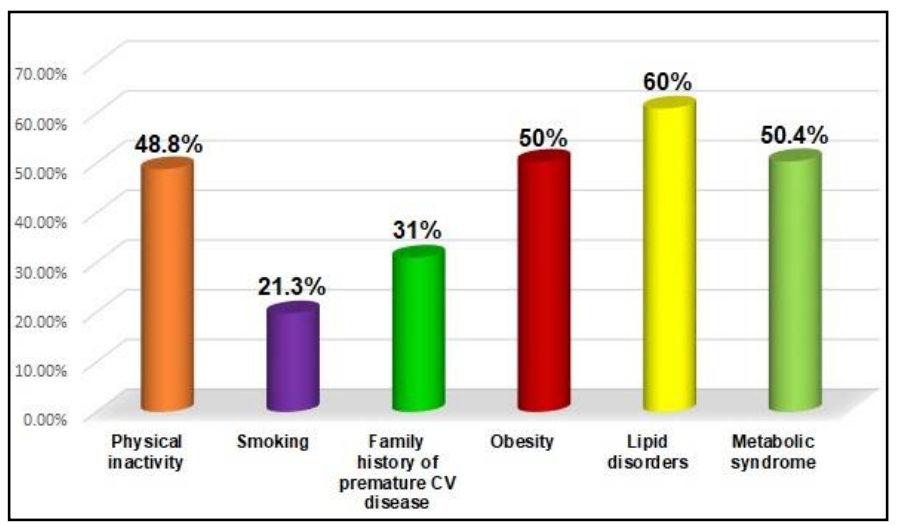

Figure 2. Prevalence of risk factors in the hypertension with chronic kidney disease study group

The diagnosis of CKD was based on the following criteria: (1) moderate impaired kidney function (eGFR reduced $<60 \mathrm{~mL} / \mathrm{ml} / \mathrm{min} / 173 \mathrm{~m}^{2}$ ) and/or on (2) structural damage of the kidney, of which the most important was the presence of albuminuria $>30 \mathrm{mg} /$ day (ACR $30 \mathrm{mg} / \mathrm{g}$ ), even in the presence of a normal or high eGFR. The risk factors of the study group with CKD are presented in Figure 2, the most fervent being lipid disorders, metabolic disorders and sedentary lifestyle.

The reduction of eGFR was in our study the most fervent diagnostic criteria of CKD, being present in $11.59 \%$ (114 cases) of the total studied hypertensive population, followed by albuminuria present in $5.49 \%$ (54 cases). The association of reduced eGFR and albuminuria was present in $3.73 \%$ (37 cases), as illustrated in figure 1. The high prevalence of CKD in the present study can be explained by the characteristics of the study subjects, presenting older age and a high prevalence of diabetes.

Sex specific prevalence of CKD. Of the 131 hypertensive with CKD, a number of $78(59.5 \%)$ were female and $53(40.5 \%)$ were men, $\mathrm{p}<0.001$, OR $1.5,95 \% \mathrm{CI}=1.39-1.82$. The higher prevalence of CKD in women can be in part be explained by the naturally lower filtration rate in women, which can result in an overestimation of CKD in female. The prevalence of CKD in female gender in the whole hypertension group of 984 patients was $15.24 \%$ (78 cases), 95\% CI 12.9-16.8. Prevalence in male gender of CKD was lower, respectively $11.23 \%$ (53 cases), 95\% CI 9.6-13.9\%. The mean age of the hypertensive population with CKD was $65.8 \pm 12.5$ years, being much higher than of the total 
hypertensive population, $\mathrm{OR}=1.151,95 \% \mathrm{CI}=1.112-1.194, \mathrm{p}<0.001$, demonstrating that older age is associated with the reduction of the renal function and the development of CKD.

Table 1. Prevalence of chronic kidney disease in hypertesnion depending on age groups

\begin{tabular}{|c|c|c|c|}
\hline Age group- years & $\begin{array}{c}\text { Nr of cases with CKD } \\
(131)\end{array}$ & $\begin{array}{c}\text { Prevalence of } \\
\text { CKD \% }\end{array}$ & $\mathbf{9 5 \%}$ CI \\
\hline $18-30$ years & 9 & 6.87 & $4.5-8.6 \%$ \\
\hline $31-40$ years & 13 & 9.93 & $7.6-12.3 \%$ \\
\hline $41-50$ years & 18 & 13.74 & $9.8-16.2 \%$ \\
\hline $51-60$ & 25 & 19.09 & $15.2-22.1 \%$ \\
\hline $61-70$ & 30 & 22.90 & $19.7-28.1 \%$ \\
\hline$>70$ & 36 & 27.48 & $24.8-30.6 \%$ \\
\hline
\end{tabular}

The repartition in CKD stages of the total hypertensive population (984 cases) was made in 4 groups: (I) class 1 CKD, (II) class 2 CKD, (III) class 3 CKD and (IV) class 4 and 5 CKD (analysed together due to the low number of patients). The CKD stages of the total hypertension study group are presented in Figure 3. As detected, the majority of hypertensive patients with CKD belonged to the stage 3 of CKD $(9.66 \%)$, followed by stage $2(1.80 \%)$ and stage $3(1.73 \%)$ as presented in Figure 3. The very low prevalence of stages 4-5 CKD can be explained due to the low naturally prevalence of end stage renal disease in hypertension and due to the fact that these severe ill patients are monitored mainly by nephrologists and not in primary care, being not included in studied that implied voluntary participation and visits to their GPs. Regarding the evaluation of the eGFR, in the 131 patients of the hypertension study group with CKD, $114(87.01 \%)$ patients presented eGFR $<90 \mathrm{ml} / \mathrm{min} / 173 \mathrm{~m}^{2}$, of which the majority of $72.5 \%$ belonged to stage 3 CKD with eGFR $<60 \mathrm{ml} / \mathrm{min} / 173 \mathrm{~m}^{2}$. The prevalence of early stages of CKD (stage 1 and 2) was noticed in our study to be lower, respectively $26.76 \%$ (Figure 4).

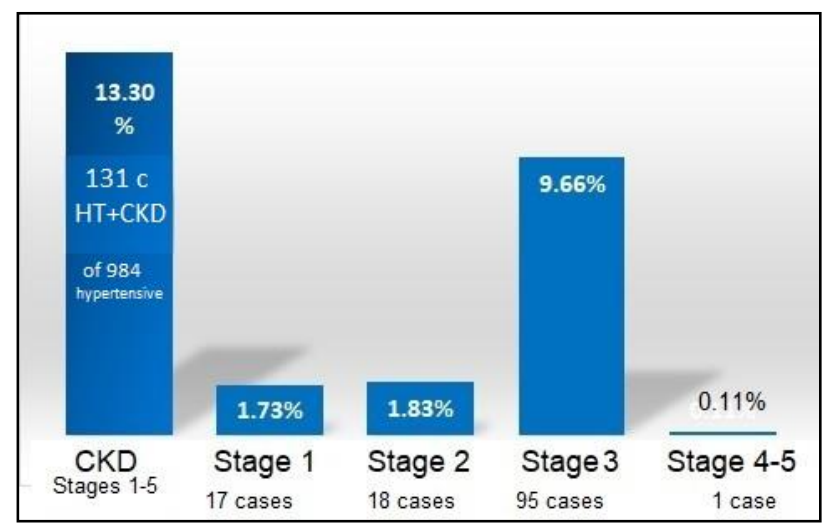

Figure 3. Prevalence of stages of chronic kidney disease in the whole hypertension study population $(\mathrm{n}=984)$

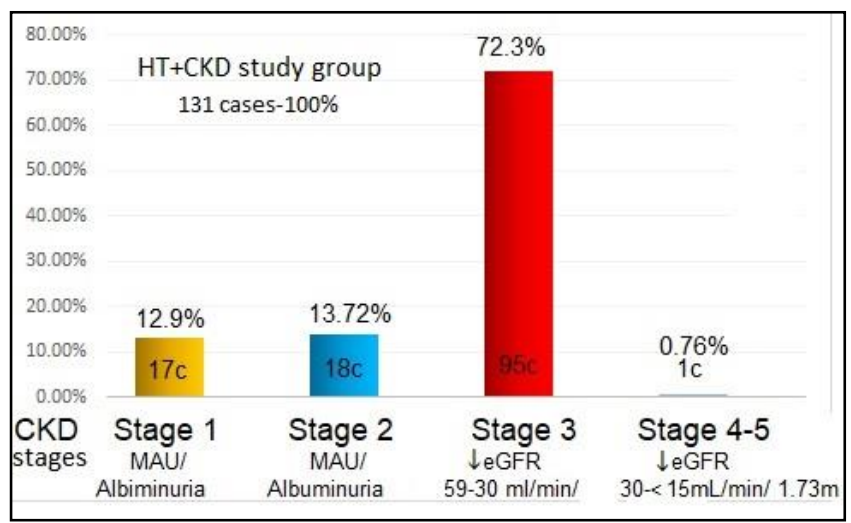

Figure 4. Repartition of CKD stages in the hypertension study group with chronic kidney disease

The prevalence of CKD in the hypertensive study population, depending on age groups, increased with progression to older age and is presented in Table 1 . In the over 70 years hypertensive patients group the prevalence of CKD was the greatest, respectively $27.48 \%$. As the population become older, an exacerbation of the burden of CKD was noticed. A percentage of $42.7 \%$ hypertensive subjects (56 cases) of those over 65 years associated CKD in our study. 


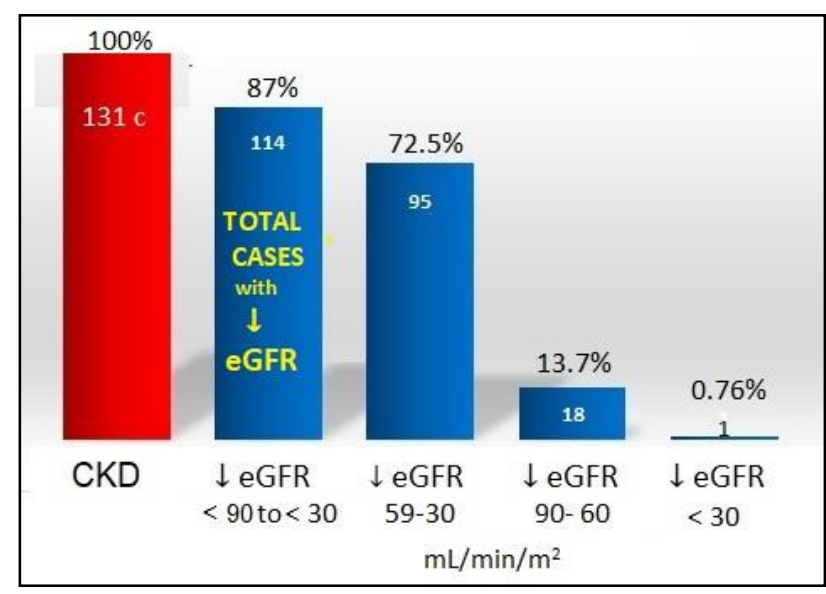

Figure 5. Prevalence of reduced eGFR in the hypertension group with chronic kidney disease

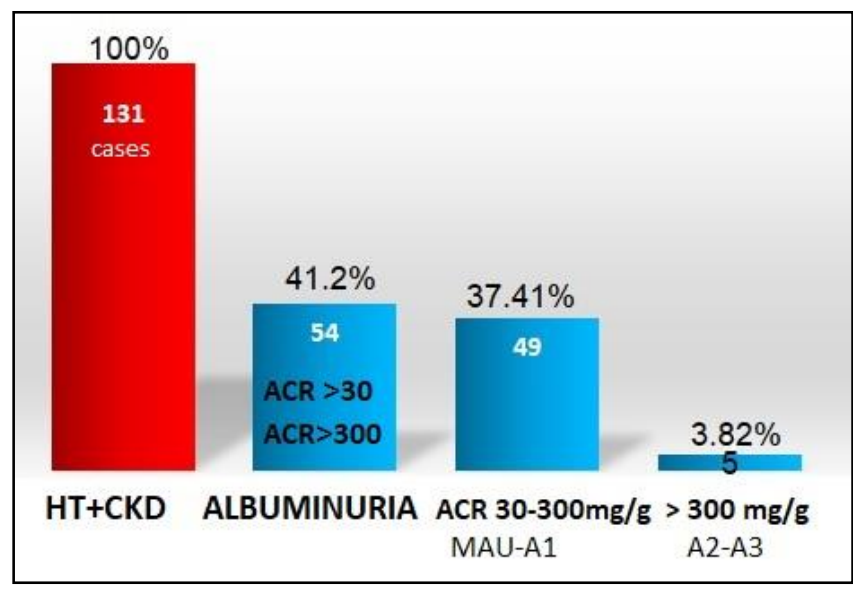

Figure 6. Prevalence of albuminuria in hypertension group with chronic kidney disease

In CKD hypertensive patients, the prevalence of albuminuria, compared with the prevalence of reduced eGFR, was lower. Albuminuria was diagnosed in $41.2 \%$ of the study group with CKD, being represented by microalbuminuria in the majority of cases (Figure 6). The prevalence of albuminuria in the total hypertension study group (984 cases) was similar both for men and female $(5.51 \%$ vs. $5.47 \%)$ OR $1.12,95 \% \mathrm{CI}=0.8-1.3)$. Concerning age, the hypertensive aged over 65 years presented more often albuminuria. Albuminuria, as component of CKD diagnosis, was statistical significant associated with the presence of diabetes and older age, but was not influenced by gender (Figure 7).

The reduced eGFR in hypertensive patients with CKD was statistical significant associated with older age, female gender and diabetes as presented in Figure 8.

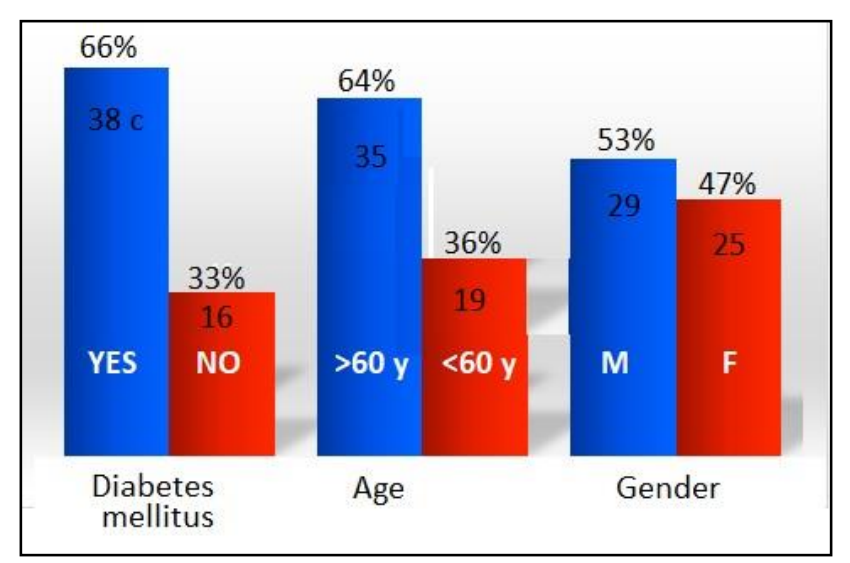

Figure 7. Dependence of albuminuria on age, gender and the presence of diabetes mellitus

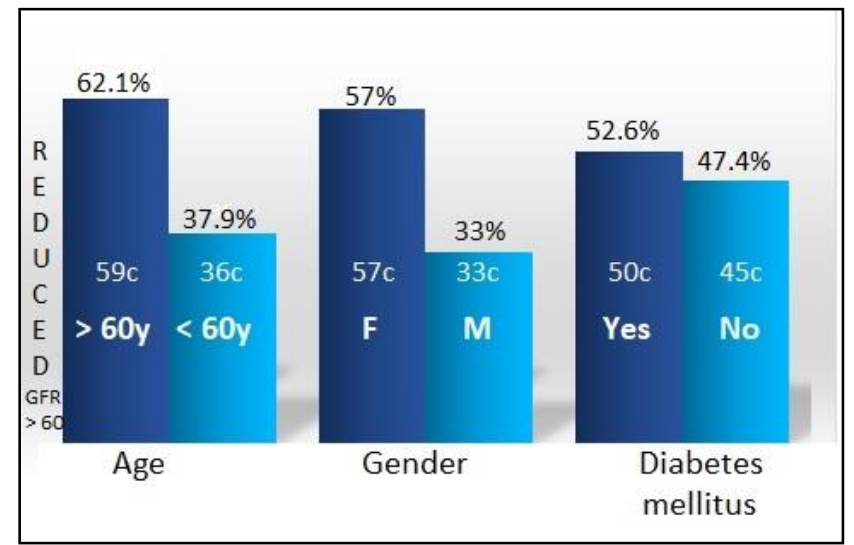

Figure 8. Dependence of estimated glomerular filtration rate on age, gender and diabetes mellitus

In order cu evaluate the factors associated prevalence of CKD in hypertension, we compared a the clinical and biochemical characteristics of a group of 142 patients with hypertension without CKD with the hypertension group with CKD (131 patients). The duration in years of hypertension was in the hypertension + CKD group greater $(65 \pm 12.5$ vs $57 \pm 11$, p $<0.01)$, systolic blood pressure (SPB) was higher, respectively $155 \pm 23$ vs $142 \pm 18 \mathrm{mmHg}$, $\mathrm{p}<0.01$ and diastolic BP (DPB) was also higher, $94 \pm 13$ vs $86 \pm 12 \mathrm{~mm} \mathrm{Hg}$. An unfavourable BP profile with nocturnal non-dipper pattern was characteristic for hypertensive patients associating CKD. 
Table 2. Cardiovascular risk factors of the hypertensive study populations with and without CKD

\begin{tabular}{|c|c|c|c|}
\hline Characteristics & $\begin{array}{c}\text { Study group } \\
\text { HTA with CKD nr.131 } \\
\end{array}$ & $\begin{array}{c}\text { Control group } \\
\text { HTA without CKD nr.142 } \\
\end{array}$ & P-value \\
\hline Male gender, n (\%) & $53(40.5 \%)$ & $56(51.56 \%)$ & 0.05 \\
\hline \multicolumn{4}{|c|}{ Age, $\mathrm{n}(\%)$} \\
\hline$>55 \mathrm{y}$ in male & $74(57 \%)$ & $65(45.5 \%)$ & 0.03 \\
\hline$>65 \mathrm{y}$ in female & $60(45.8 \%)$ & $60(48 \%)$ & 0.44 \\
\hline Family history of premature CVD, n (\%) & $42(31 \%)$ & $25(19.53 \%)$ & 0.02 \\
\hline Smoking, $\mathrm{n}(\%)$ & $28(21.3 \%)$ & $25(17.6 \%)$ & 0.82 \\
\hline High LDL-c, n (\%) & $68(52 \%)$ & $65(45.5 \%)$ & $<005$ \\
\hline Low HDL-c, n (\%) & $47(35.8 \%)$ & $43(30 \%)$ & 0.06 \\
\hline Hypertriglyceridemia, n (\%) & $66(50.3 \%)$ & $43(31.6 \%)$ & $<0.05$ \\
\hline Glycaemia & $110 \pm 38.5$ & $104.2 \pm 28$ & $<0.05$ \\
\hline Sedentary lifestyle, n (\%) & $64(48.8 \%)$ & $64(45 \%)$ & 0.4 \\
\hline $\mathrm{T}_{2} \mathrm{DM}, \mathrm{n}(\%)$ & $34(26.4 \%)$ & $30(21.8 \%)$ & $<0.05$ \\
\hline BMI $\left(\mathrm{kg} / \mathrm{m}^{2}\right), \mathrm{n}(\%)$ & 28.3 & 27.4 & 0.7 \\
\hline Mean BMI $\left(\mathrm{kg} / \mathrm{m}^{2}\right)$ & $29.82 \pm 6.53$ & $27.81 \pm 5.45$ & 0.05 \\
\hline
\end{tabular}

$\mathrm{T}_{2} \mathrm{DM}$, type 2 diabetes mellitus; LDL-c, low density lipoprotein cholesterol, HDLc, high density lipoprotein cholesterol; BMI, body mass index.

Patients with CKD presented more frequent abnormalities included in the metabolic syndrome, consisting in high glycaemia, reduced HDL cholesterol, raised triglycerides and obesity, factors that also contributed to their high cardiovascular risk associated with hypertension (Table 2). The laboratory abnormalities noticed in hypertension with CKD are presented in table 3.

Table 3. Biochemical data in hta study groups with and without choric kidney disease

\begin{tabular}{|c|c|c|c|}
\hline Variables $\mathbf{E S D}$ & $\begin{array}{c}\text { Hypertension } \\
\text { without CKD } \\
(\mathrm{nr}=142)\end{array}$ & $\begin{array}{c}\text { Hypertension } \\
\text { with CKD }(\mathrm{nr}=131)\end{array}$ & $\begin{array}{c}\text { P } \\
\text { value }\end{array}$ \\
\hline Fasting glucose, $\mathrm{mg} / \mathrm{dL}$ & $102 \pm 28$ & $110 \pm 38.5$ & 0.03 \\
\hline HbAIc, $\%$ & $5.6 \% \pm 0.9$ & $5.8 \% \pm 1.8$ & 0.04 \\
\hline LDL cholesterol mean \pm SD, mg/dL & $124 \pm 33$ & $127 \pm 35$ & 0.06 \\
\hline HDL Cholesterol \pm SD, mg/dL & $46 \pm 17$ & $40 \pm 18 \mathrm{mg} / \mathrm{dL}$ & 0.04 \\
\hline Triglycerides, mg/dL & $135 \pm 95$ & $141 \pm 98.8$ & 0.08 \\
\hline Creatinine, mg/dL & $0.8 \pm 0.4 \mathrm{mg} / \mathrm{dL}$ & $1.05 \pm 0.8 \mathrm{mg} / \mathrm{dL}$ & 0.01 \\
\hline Uric acid, mg/dL & $4.3 \pm 1.8 \mathrm{mg} / \mathrm{dL}$ & $5.5 \pm 1.9 \mathrm{mg} / \mathrm{dl}$ & 0.04 \\
\hline Hb, mg/dL & $14.1 \pm 1.43$ & $13.7 \pm 1.29$ & 0.6 \\
\hline $\mathrm{eGFR}, \mathrm{ml} / \mathrm{min} / 1.73 \mathrm{~m}^{2}$ & $70 \pm 8$ & $58 \pm 12$ & 0.01 \\
\hline $\mathrm{ACR}, \mathrm{mg} / \mathrm{g}$ & $14 \pm 6$ & $138 \pm 24$ & 0.001 \\
\hline
\end{tabular}

Abbreviations: HbA1c, glycosylated haemoglobin; Hb, haemoglobin; eGFR, estimated glomerular filtration rate; ACR, albumin to creatinine ratio; $\mathrm{Hb}$, hemoglobin.

In a multiple logistic regression analysis model to predict CKD (Table 4), after adjusting for age, systolic and diastolic blood pressure, BMI, diabetes mellitus, dyslipidaemia, smoking status, the reduction of eGFR was significantly associated only with an older age and diabetes (OR=1.1, $95 \% \mathrm{CI}=1.076-1.2214, \mathrm{p}=0.001)$.

Table 4. Multiple logistic regression model to predict chronic kidney disease

\begin{tabular}{|c|c|c|c|}
\hline Variable & OR & 95\% CI & P value \\
\hline Age, years & 1.13 & $1.03-1.14$ & $\mathrm{p}<0.001$ \\
\hline Gender & 1.5 & $0.95-2.43$ & 0.08 \\
\hline Systolic blood pressure & 1.01 & $0.92-1.04$ & 0.16 \\
\hline Diastolic blood pressure & 0.98 & $0.92-1.01$ & 0.36 \\
\hline Body mass index & 0.97 & $0.91-0.99$ & 0.3 \\
\hline Educational level & 0.9 & $0.93-1.01$ & 0.1 \\
\hline Smoking present & 0.83 & $0.49-1.02$ & 0.47 \\
\hline Diabetes mellitus & 1.27 & $1.1-1.38$ & $\mathrm{p}<0.001$ \\
\hline
\end{tabular}


This present study is to the authors' knowledge the first study made in Timis County, which evaluated in primary care patients the prevalence of CKD associated to essential arterial hypertension. The prevalence of CKD in hypertension among different trials reveals a great heterogeneity and is hampered by differences in the definition of CKD, study design, methodology, data reporting and different evaluation methods. In older studies, based on serum creatinine concentration, as marker of renal function, the prevalence of CKD in essential hypertension was low $(<2 \%)$. The global tendency noticed presently is the growing prevalence of CKD secondary to hypertension. There great differences between studies regarding the prevalence of CKD, depend on racial and ethnic groups factors, genetic factors, lifestyle conditions and study methods. Most of the studies assessed the prevalence of CKD in the general population to be 5-8\%, and in arterial hypertension to be 10-30\% $[12,13]$. Analysing CKD secondary to hypertensive nephroslerosis, our data showed that a relevant percentage of patients with arterial hypertension (13.32\%) develop in evolution this complication. There are few studies in primary care that estimate the prevalence and severity of CKD in hypertensive subjects using the KDOIGO classification as many trials analysed CKD when eGFR was <60 $\mathrm{ml} / \mathrm{min} / 1.72 \mathrm{~m}^{2}$. Literature data regarding the prevalence of CKD in hypertension are very inhomogeneous, (ranging from 6 to $45 \%$ ). In a cross-sectional survey conducted in a primary care population, the prevalence of CKD in patients with hypertension was $21 \%$, the most frequent stage being stage 3 CKD [14]. As noticed in our study, the presence of CKD was associated with old age, female gender, high values of systolic BP and diabetes mellitus [15-17]. In the SEPHAR II Survey (2012) regarding the evaluation of hypertension in Romania, microalbuminura was present in $7.1 \%$, macroproteinuria in $1.4 \%$, mild renal impairment with eGFR $90-60 \mathrm{~mL} / \mathrm{min} / \mathrm{m}^{2}$ in $41 \%$ and moderate severe renal impairment with eGFR $<60 \mathrm{~mL} / \mathrm{min} / 1.73 \mathrm{~m}^{2}$ in $5.6 \%$. In the SEPHAR III Survey (2016) albuminuria between $30-300 \mathrm{mg} / \mathrm{g}$ was present in $4.9 \%$ of the hypertensive population, eGFR between $30-59 \mathrm{~mL} / \mathrm{min} / 1.73 \mathrm{~m}^{2}$ was present in $4.6 \%$, eGFR $<30 \mathrm{~mL} / \mathrm{min} / 1.73 \mathrm{~m}^{2}$ was present in $0.7 \%$ and albuminuria $>300 \mathrm{mg} / \mathrm{g}$ in $2.2 \%$ [8-10]. The prevalence of CKD in the general population of Turkey evaluated in the CREDIT Study was $25.3 \%$, of which $56 \%$ had hypertension, the prevalence of hypertension being the greatest in stage 3 CKD (79\%) and in stage $5(92.3 \%)$. The control rate of hypertension with CKD was in this study low, as only $33 \%$ of patients reached target BP. In a multicentre cross-sectional survey in Ghana, CKD in hypertension was even more common, with a prevalence of $46.9 \%$. Albuminuria was present in $28.9 \%$, being higher in stage 2 and 4 than in stage 3 and 5. An explanation for these very large differences in the prevalence of CKD between European countries and Africa is not yet available [18]. A high prevalence of CKD was found also in African Americans, who share a common ancestry with the population of Ghana and who have an adjusted risk of ESRD that is 3.7 times higher, compared with Caucasian Americans. As the epidemiology of hypertension associating CKD is variable in different countries, it is important to perform national studies to determine prevalence and implement early diagnostic methods, prevention strategies and the best treatment options [19]. These measures are necessary for preventing the evolution of CKD to advanced stages, which affect the quality of life, are associated with a high risk of cardiovascular complications and impose finally renal replacement therapy [20-22]. Though the European Hypertension Guidelines recommend screening for CKD in hypertension and diabetes, a generally inertia is noticed at the level of primary care physicians for routine search for albumin to creatinine ratio and for evaluation eGFR. As CKD is asymptomatic in early stages, it is frequently undiagnosed. The determination of the creatinine level is not enough to evaluate renal function, early stages of CKD being missed by this approach. As mild and moderate severe hypertension subjects are usually treated in primary care, it appears to be necessary to include at this level a routine evaluation of CKD [23, 24]. There are concerns that the KDIGO definition of CKD might sometimes determine untrue identification of CKD. The calculation of eGFR with MDRD formula, used in many studies, possible overestimated CKD stages, but CKD-EPI equation, on which our study was based (corrected for nonrenal influences as age, gender and race), is appreciated to be a more accurate predictor of renal function. A possible error factor regarding the diagnosis of CKD is represented by the creatinine level 
of the patient, on which is based the CKD-EPI formula. This level can vary largely at the same subject (till $21 \%$ during a two weeks interval) and rises with age.

The reduced eGFR is not only a marker of renal function failure, but data from studies, as the ARIC (Atherosclerosis Risk on Communities), have demonstrated that the eGFR is also an independent risk factor for atherosclerotic cardiovascular disease [25-28]. The request of GPs for albuminuria and eGFR in daily practice is unsatisfactory low, not surpassing 20-25\% and demonstrating the need for better implementation of hypertension guidelines in primary care practice [26-30].The predominant female gender repartition of CKD was also found in other surveys. Men have less often a decreased eGFR than women, as the lower muscle mass of women can influence the creatinine level. We noticed a strong connection of CKD with the aging of the study population, data confirmed in other studies [27, 28]. The repartition in CKD stages demonstrated the greatest prevalence of stage 3, followed by stage 2 and the lowest prevalence in stage 4 . The great incidence of cardiovascular diseases, diabetes mellitus, dyslipidaemia, metabolic syndrome and hyperuricemia met in our study was also noticed in other surveys, in which comorbidities were registered in $50-85 \%$ of the hypertensive population with CKD [29-33].

Limitations of the study result from the cross-sectional design. Follow up data were registered only from few participants, so that information regarding the evolution and aggravation in time of CKD and the factors that can worsen kidney function and aggravate albuminuria were not available. Other limits were the selection of the study population was based on visits to the GPs, a single determination of albuminuria and of eGFR, aspects that could introduce bias.

\section{Conclusions}

The prevalence of CKD in hypertensive patients monitored in primary care offices in Timis County was $13.32 \%$. Prevalence of CKD was higher in female than in men, in older ages and in the presence of association of hypertension with diabetes and other cardiovascular disease. Associated risk factors as family history of cardiovascular disease, educational level, obesity, systolic and diastolic blood pressure, dyslipidaemia, although presenting higher levels in CKD, in a multivariate analysis did not reach statistical significance regarding the association with the prevalence of CKD in essential hypertension. The study data outline the importance of early detection of CKD in primary care and justifies intensification of cardiovascular risk management, especially concerning the reduction of high blood pressure to target values, the use the of renin-angiotensin system blockers, in order to reduce albuminuria and the necessity of intensive treatment of other risk factors as dyslipidaemia.

\section{References}

1.MUle, G., CAlCATERRA, I., COSTANZO, M., GERACI, G., GUARINO, L., FORACI, A.C., VARIO, M.G., CERASOLA, G., COTTONE, S., Relationship Between Short-Term Blood Pressure Variability and Subclinical Renal Damage in Essential Hypertensive patients, J Clin Hypertens (Greenwich), 17(6), 2015, 476-480.

2.CHEN, F., YANG, W., WENG, J., JIA, W., JI, L., XIAO, J., SHAN, Z., LIU, J., TIAN, H., JI Q, ZHU, D., GE, J., LIN, L., CHEN, L., GUO, X., ZHAO, Z., LI, Q., ZHOU Z, SHAN G, LU J., Albuminuria: Prevalence, associated risk factors and relationship with cardiovascular disease, J Diabetes Investig, 5(4), 2014, 464-471.

3.ARDELEANU, E., DOROBANȚU, M., DARABONT,, R., LIGHEZAN, D., LIGHEZAN, R., PURCĂRIȚĂ, D., DELEANU, A., GURGUS, D., NICOLA, P., BAAJ, S., Prevalence of microalbuminuria in hypertension monitored in primary care, Practica Medicala, 10(1), 2015, 50-55.

4.CEPOI V., ONOFRIESCU M., SEGALL L., COVIC A., The Prevalence of chronic kidney disease in the general population in Romania: a study on 60,000 persons, Int Urol Nephrol, 44, 2013, p. 213, DOI 10.1007/s 11255-011-9923-z 
5.FOLEY, R., WANG, C., COLliNS, A., Cardiovascular Risk Factor Profiles and Kidney Function Stage in the US General Population: The NHANES III Study, Mayo Clinic Proceedings, 80(10), 2012, 1270-1277.

6.WILLIAMS, B., MANCIA, G., SPIERING, W., AGABITI ROSEI, E., AZIZI, M., BURNIER, M., CLEMENT, D.L., COCA, A., DE SIMONE, G., DOMINICZAK, A., KAHAN, T., MAHFOUD, F., REDON, J., RUILOPE, L., ZANCHETTI, A., KERINS, M., KJELDSEN, S.E., KREUTZ, R., LAURENT, S., LIP, G.Y.H., MCMANUS, R., NARKIEWICZ, K, RUSCHITZKA, F., SCHMIEDER, R.E., SHLYAKHTO, E., TSIOUFI, S.C., ABOYANS, V., DESORMAIS, I., 2018 ESC/ESH Guidelines for the management of arterial hypertension. The Task Force for the management of arterial hypertension of the European Society of Cardiology (ESC) and the European Society of Hypertension (ESH), Eur Heart J, 39, 2018, 3021-3104.

7.PIEPOLI, M.F., HOES, A.W., AGEWALl, S., AlBuS, C., BROTONS, C., CATAPANO, A.L., COONEY, M.T., CORRA, U., COSYNS, B., DEATON, C., GRAHAM, I., HALL, M.S., HOBBS, F.D.R., LOCHEN, M.L., LÖLLGEN, H., MARQUES-VIDAL, P., PERK, J., PRESCOTT, E., REDON, J., RICHTER, D.J., SATTAR, N., SMULDERS Y, TIBERI M, VAN DER WORP HB, VAN DIS I, VERSCHUREN, W., BINNO, S., 2016 European Guidelines on cardiovascular disease prevention in clinical practice. Eur. Heart J, 37, 2016, 2315-2381.

8.DOROBANTU, M., DARABONT, R., DIMULESCU, D., SINESCU, C., GUSBETH, P.T., GEORGESCU, C.A., MITU, F., LIGHEZAN, D., POP, C., BABES, K., GIUCA, A., BRINZA, I., UDRESCU, M., HERDEA, V., TAUTU, O., New national epidemiological survey for the assessment of trend in hypertension's prevalence, treatment and control among the adult population of Romania: SEPHAR III: design and methodology, J Hypertens Res, 2, 2016, 143-152.

9.DOROBANŢU, M., DARABONT, R., GHIORGHE, S., ARSENESCU-GEORGESCU, C., MACARIE, C., MITU, F., LIGHEZAN, D., MUSETESCU, R., POP, C., ARDELEANU, E., CRAIU, E., TĂUTU, O.F., Hypertension prevalence and control in Romania at a seven-year interval. Comparison of SEPHAR I and II surveys, J Hypertens, 32(1), 2014, 39-47.

10.DOROBANTU, M., TAUTU, O.F., DIMULESCU, D., SINESCU, C., GUSBETH-TATOMIR, P., ARSENESCU-GEORGESCU C, MITU F, LIGHEZAN D, POP C, BABES K, GIUCA A, BRANZA I, UDRESCU, M., HERDEA, V., DARABONT, R., Perspectives on hypertension's prevalence, treatment and control in a high cardiovascular risk East European country: data from the SEPHAR III survey, J Hypertens, 36(3), 2018, 690 -700.

11.LEVIN, A., STEVENS, P.E., Summary of KDIGO 2012 CKD Guideline: behind the scenes, need for guidance and a framework for moving forward, Kidney int. 85(1), 2014, 49-61.

12.PASCUAL, J.M., RODILlA, E., COSTA, J.A., GARCIA-ESCRICH, M., GONZALEZ, C., REDON, J., Prognostic value of microalbuminuria during antihypertensive treatment in essential hypertension, Hypertension, 64(6), 2014,1228-1234.

13.SCHMIEDER, R.E., MANN, J.F., SCHUMACHER, H., GAO, P., MANCIA, G., WEBER, M.A., ONTARGET Investigators. Changes in albuminuria predict mortality and morbidity in patients with vascular disease, J Am Soc Nephrol, 22, 2014, 1353-1364.

14.HSU, C.C., BRANCATI, .FL., ASTOR, B.C., KAO, W.H., STEFFES, M.W., FOLSOM, A.R., CORESH, J., Blood pressure, atherosclerosis and albuminuria in 10113 participants in the Atherosclerosis Risk in Communities Study, J Hypertens, 27(4), 2009, 397-409.

15.GURGUS, D., ARDELEANU, E., GADAU, C., FOLESCU, R., TILEA, I., VARGA, A., ZAMFIR, A., BAAJ, T., Prevalence, Biochemical and Clinical Characteristics of Resistant Hypertension, Rev. Chim., 69(10), 2018, 2845-49.

16.GADAU, C., ARDELEANU, E., FOLESCU, R., TILEA, I., VARGA, A., ZAMFIR, A., BAAJ, T., BOANCA, A., Prevalence, Characteristics and Predictive Factors of Microalbuminuria in Resistant Systemic Arterial Hypertension, Rev. Chim., 69(9), 2018, 2425-2429. 
17.NICOLA, P., ARDELEANU, E., GADAU, C., DOROBANTU, M., DARABONT, R., TILEA, I., VARGA, A., BAAJ, T., Evaluation of Biochemical and Clinical Parameters of Hypertension with Type 2 Diabetes Mellitus, Rev. Chim., 69(9), 2018, 2402-2406.

18. MATSUSHITA, K., VAN DER VELDE, M., ASTOR, B.C., WOODWARD, M., LEVEY, A.S., DE JONG, P.E., Association of estimated glomerular filtration rate and albuminuria with all-cause and cardiovascular mortality in general population cohorts: a collaborative meta-analysis, Lancet, $\mathbf{3 7 5}$, 2010, 2073-2081.

19.GERACI, G., MUlE, G., MOGAVERO, M., GERACI, C., D’IGNOTI, D., GUGLIELMO, C., Renal haemodynamics and severity of carotid atherosclerosis in hypertensive patients with and without impaired renal function, Nutr Metab Cardiovasc, 25(2), 2015, 160-166.

20.CERASOlA, G., MUle, G., COTTONE, S., NARDI, E., CUSiMANO, P., Hypertension, microalbuminuria and renal dysfunction: the Renal Dysfunction in Hypertension (REDHY) study, $\mathrm{J}$ Nephrol, 21, 2008, 368-373.

21.ARDELEANU, E., LIGHEZAN, D., LIGHEZAN, R., GURGUS, D., DELEANU, A., POPOVICI, M., SUCIU, R., NICOLA, P., PURCARIŢA, D., Evolution of Carotid Atherosclerosis in Type 2 Diabetes and Hypertension, Medicine in Evolution, 20 (4), 2014, 548-557.

22.ARDElEANU, E., LiGHEZAN, D., DELEANU, A., GURGUS, D., POPOVICI, M., SUCIU, R., NICOLA,P., Uncontrolled Hypertension in Primary Care, Practica Medicală, IX(4), 2014, 272-279.

23.ARDELEANU, E., LIGHEZAN, D., LIGHEZAN, R., DELEANU, A., GURGUS, D., POPOVICI M., NICOLA, P., BAAJ, S., Nonaderence to antihypertensive treatment in primary care. J. Hypertension, 33(1), 2014, 410.

24.TILEA, I. PETRA, D., VOIDAZAN, S., ARDELEANU, E., VARGA, A., Treatment adherence among adult hypertensive patients: a cross-sectional retrospective study in primary care in Romania.

Patient Preference and Adherence, 12, 2018, 625-635.

25.ABU-AWWAD A, FOLESCU R, POP DL, MOTOC AGM, OPREA DM, TUDORAN M, ZAMFIR CL, FAUR CI, VERMESAN D, DELEANU BN, ANDOR BC, HARAGUS HG. Morphometric characteristics of fibrocartilaginous tissue in the herniated intervertebral disc. Rom $\mathrm{J}$ Morphol Embryol, 2019, 60(2):629-634

26. GAMAN, M.A., DOBRICA, E.C., PASCU, E.G., COZMA, M.A., EPINGEAC, M.E., GAMAN, A.M., PANTEA STOIAN, A.M., BRATU, O.G., DIACONU, C.C. Cardio metabolic risk factors for atrial fibrillation in type 2 diabetes mellitus: Focus on hypertension, metabolic syndrome and obesity, J Mind Med Sci. 6(1), 2019, 157-161

27.YOKOYAMA, H., AOKI, T., IMAHORI, M., KURAMITSU, M., Subclinical atherosclerosis is increased in type 2 diabetic patients with microalbuminuria evaluated by intima-media thickness and pulse wave velocity, Kidney Int, 66, 2004, 448-454.

28.HORODINSCHI, R.N., STANESCU, A.M.A., BRATU, O.G., PANTEA STOIAN, A., RADAVOI, D.G., DIACONU, C.C. Treatment with statins in elderly patients, Medicina. 55(11), 2019, 721; doi:10.3390/medicina55110721.

29.DIERCKS, G.F., VAN BOVEN, A.J., HILLEGE, H.L., JANSSEN, W.M., KORS, J.A., DE JONG, P.E., Microalbuminuria is independently associated with ischaemic electrocardiographic abnormalities in a large nondiabetic population. The PREVEND (Prevention of Renal and Vascular ENdstage Disease) study, Eur Heart J, 21, 2000, 1922-1927.

30.LEVY, A., CORESH, J., Chronic Kidney Disease, Lancet, 379, 2012, 165-180.

31.SEGURA, J., CAMPO, C., GIL, P., ROLDAN, C., VIRGIL, L., RODICIO, J., RIULOPE, L., Development of Chronic Kidney Disease and Cardiovascular Prognosis in Essential Hypertensive Patients, J. Am. Nephrol, 15(2), 2004, 1616-1622.

32.AHMED, A.A., PREJBEANU, R., VERMESAN, D., DELEANU, B., IONITESCU, M., FLORESCU, S., VLAD, C.D., DUMITRASCU, V., Dose Effect of Local Betamethasone Injection in Low Back Pain, Rev. Chim., 69(9), 2018, 2382-2384. 
33.ARDELEANU, E., LIGHEZAN, D., LIGHEZAN, R., DELEANU, A., GURGUS, D., POPOVICI, M., NICOLA P, BAAJ S. Evolution of carotid atherosclerosis in type 2 diabetes and hypertension. J. Hypertension, 32(1), 2014, 673.

34.ARDELEANU, E., DOROBANȚU, M., LIGHEZAN, D., DARABONT,, R., GURGUȘ, D., DELEANU, A., NICOLA, P., SCRIPCA, M., TĂUTU, O. Evaluation of resistant hypertension in primary care settings. J. Hypertension Research, 1(2), 2015, 53-59.

$\overline{\text { Manuscript received: } 16.05 .2020}$ 